\title{
Classification of Weathering in Rocks and Its Engineering Implications
}

\author{
A Patel* \\ Department of Civil Engineering, Visvesvaraya National Institute of Technology, India
}

Submission: September 06, 2017; Published: September 22, 2017

*Corresponding author: A Patel, Department of Civil Engineering, Visvesvaraya National Institute of Technology, Nagpur-440010, India,

Email: anjanp14@gmail.com

Abstract

A critical review on the description and classification of weathering in rocks has been presented in this paper. This paper starts with a brief description on several factors causing weathering in rocks followed by the weathering mechanism and the description of weathering in rocks. A review of existing codes and guidelines on weathering and its implications to describe the engineering properties of rocks has been presented. From the point of view that weathering process modify the mass engineering properties of rocks which are quite unpredictable, this type of review work becomes necessary. The present paper forms a useful source of information for geologists and geotechnical engineers working on weathered rocks.

Keyword: Rock; Weathering; Classification; Guidelines; Engineering properties

\section{Introduction}

Weathering of rocks is a purely subjective term and is defined differently by different authors [1-4]. However, weathering in general is the process which brings about several changes to the properties of rock mass due to its exposure to changing environmental (physical, chemical and biological) conditions and hence from the engineering point of view, grading of weathering becomes very important. The alteration in the engineering properties of rocks due to weathering may occur at the material scale (rock strength, swelling potential, slaking index, compressibility, consolidation characteristics etc.) and/or mass scale (discontinuities, fracture, joint, settlement, permeability etc.), as reported in the literature [4-12]. Moreover, behavior of the weathered rocks depends upon the environmental conditions, which it is further exposed to. For example, weathered rocks in dry condition may swell or start disintegrating, when coming in contact with water [13]. Similarly, different applications place emphasis on different attributes of the weathered rocks [14]. When constructing a building on weathered rocks, the engineer will be interested more on its bearing capacity; whereas in case of slopes and embankments he is more concerned with changes in permeability as a result of weathering [15]. However, grading weathered rocks is a very difficult task and as a result, the modification in various engineering properties of a weathered rock is quite unpredictable and can't follow any calculation technique $[4,16]$. In addition, engineering may expose the rock mass to a new environment and weathering may continue even after the construction has been over. Efforts have been made by the researchers, engineers and geologists to classify weathered rocks and its effects on various engineering properties of rock mass. Moreover, codes and guidelines have been formulated by the individuals (Table 1) and the international societies like International Society for Rock Mechanics [17] and the Engineering Group of Geological Society Working Party. In this paper, a review on various aspects of these guidelines and its engineering implications has been highlighted.

\section{Weathering of Rocks}

Weathering in rocks is a very complex phenomenon that can be presented in a matrix form in (Figure 1). It is not only the environmental conditions and the rock properties on which the rate of weathering will depend but also the combination of these factors, duration of exposure and the types of environmental cycles (like wetting-drying, freeze-thaw etc.) that matters the most. Moreover, it is the distribution and concentration of the weather-resistant (e.g., quartz, feldspar etc.) and weather prone minerals (e.g., biotitic, muscovite, hornblende etc.), that will affect the grade of weathering [4,18-20].

In spite of these limitations, some of the researchers [16,2023] have tried to correlate the rate of weathering through various laboratory tests including X-ray diffraction (XRD) analysis; study of minerals using Scanning electron microscope (SEM); measurement of specific surface area (SSA), total cation 


\section{Civil Engineering Research Journal}

exchange capacity (TCEC), type of exchangeable cations and the $\mathrm{pH}$ value. These relationships are very helpful for understanding the weathering mechanism in different types of rocks. For example, weathering due to temperature is more on dark rocks such as basalt but is less on white rocks like chalk [4]. On the other hand, weathering due to the effects of chemical fluids will be more on chalks than basalt.

\begin{tabular}{l} 
Environmental factors \\
Temperature \\
Moisture \\
Chemical fluids \\
Biological agencies \\
\hline
\end{tabular}

Exposure time; varying condition of different environmental factors; combination of environmental factors and rock properties

\section{Rock Poperties \\ Mineralogical composition; \\ Fabric and grain structure; \\ Structural defects (viz. joints. discontinuities fracture etc.)}

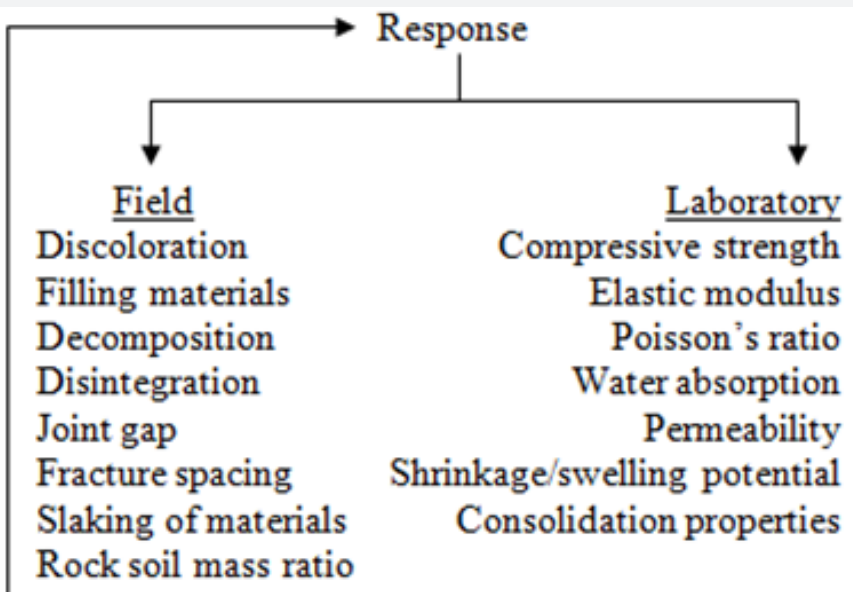

Figure 1: A matrix of various parameters causing weathering in rocks.

Rocks of sedimentary and metamorphic origin (such as clay shale's, poorly to moderately cemented sandstones, marl, and anhydrite) are very moisture-sensitive and hence get weathered due to reaction with water [14]. Basic and ultra basic igneous rocks, metamorphic rocks, limestone, sandstone and mudshale, which contain plenty of silicate minerals, easily convert into clay minerals such as montmorillonite, illite and kaolinite Table 1: Some classification systems for weathered rocks.

\begin{tabular}{|c|c|c|}
\hline References & Major Descriptive Terms & Origin/Applicability \\
\hline Moye [26] & $\begin{array}{l}\text { Joints strain, Rock and soil material strain, Feldspar } \\
\text { decomposition, Strength of NX core samples, } \\
\text { Disintegration in water, Biotitic decomposition and } \\
\text { presence or absence of original texture }\end{array}$ & $\begin{array}{l}\text { Weathering of granites in the Snowy } \\
\text { Mountains, Australia }\end{array}$ \\
\hline Ruxton \& Berry [27] & Concept of rock : soil ratio & Weathered granite in Hongkong \\
\hline Little [28] & Concept of rock : soil ratio & Weathered granite \\
\hline Dearman [6], Anon [29]: BS 5930 & $\begin{array}{l}\text { Discoloration, decompositions, disintegration and } \\
\text { freshness }\end{array}$ & Mass weathering grade \\
\hline Stapledon [30] & $\begin{array}{l}\text { condition-terms combined with descriptive terms } \\
\text { for rock material strength }\end{array}$ & $\begin{array}{c}\text { Wide range of rock types in varying structural } \\
\text { conditions, Australia }\end{array}$ \\
\hline Dames \& Moore [31] & Modification to BS 5930 & $\begin{array}{l}\text { granitic residual soil and sedimentary } \\
\text { residual soil, Singapore }\end{array}$ \\
\hline Komoo \& Mogana [32] & $\begin{array}{l}\text { Material fabric (texture), discoloration, } \\
\text { discontinuity surface, }\end{array}$ & $\begin{array}{l}\text { Metamorphic rock (Clastic Metasediment) in } \\
\text { Peninsular Malaysia }\end{array}$ \\
\hline Price [4] & $\begin{array}{l}\text { Uniformity or regularity and style of weathering } \\
\text { (uniform, complex, core stone and solution } \\
\text { weathered) }\end{array}$ & Mass weathering for engineering purposes \\
\hline $\begin{array}{l}\text { Engineering Group of Geological Society } \\
\text { Working Party [38] }\end{array}$ & $\begin{array}{c}\text { Changes in color; Changes in fracture state; } \\
\text { Reduction in strength; and Presence, character and } \\
\text { extent of weathering products }\end{array}$ & Engineering purpose \\
\hline
\end{tabular}

through oxidation and reduction, hydration and dehydration, ion exchange and leaching process [23]. Higgs [24] has reported that igneous rocks with fine-grain sizes are more weather resistant as compared to the coarse-grained types. Moreover, the deterioration in some of the rocks like basalt increase significantly due to the presence of secondary minerals which itself are product of weathering of the fresh rocks $[13,24,25$,$] .$ 


\section{Civil Engineering Research Journal}

\begin{tabular}{|c|c|c|}
\hline Hudec [16] & $\begin{array}{c}\text { Cluster analysis combining several tests (water } \\
\text { absorption, magnesium sulphate, petro graphic } \\
\text { number, rock expansion, High-Low T-cycles, Freeze- } \\
\text { thaw cycles, wetting-drying cycles, absorption SSD, } \\
\text { Impact strength, Los Angle abrasion, bulk density) } \\
\text { with similar results into groups. }\end{array}$ & Engineering purpose \\
\hline Lempe et al. [12] & $\begin{array}{c}\text { Decalcification and associated browning, } \\
\text { disintegration of dolomitic components, } \\
\text { acidification and an increase of the clay content, loss } \\
\text { of volume/mass }\end{array}$ & $\begin{array}{c}\text { Pleistocene glaciofluvial gravel rich in } \\
\text { carbonate northern Alpine foreland (Bavaria/ } \\
\text { Germany) }\end{array}$ \\
\hline
\end{tabular}

\section{Description of weathering in rocks}

Due to the effect of weathering, there occurs an overall change in the engineering properties of rock mass. Hence, from the engineering point of view, it becomes very important to classify the weathering state of a rock mass. Various researchers, engineers and geologists [4,6,12,16,26-32] have tried to do so in the past (Table 1 ). It might be easy to understand the mechanism or process of weathering in rocks through various laboratory tests, but very difficult to quantify it. As mentioned earlier, weathering is a purely subject term and there is no such calculation technique or laboratory tests available, that can quantify the amount of weathering in rock mass. Moreover, depending upon the types of engineering works, the rock mass will be further exposed to weathering that can't be predicted.
With these limitations, different classifications for different sets of environmental and rock conditions have been made.

However, it is observed that the descriptive terms used for classifying weathered rocks are purely subjective. For example, the color seen by one person will depend on the type of light source, the background, the size of the object and the colors that have been seen immediately before [14]. Moreover, many times it has been seen that there is a mismatch of these descriptive terms (e.g. colors, decomposition, disintegration, discontinuities, fracture spacing etc.) in the core logs and core photographs due to their subjective in nature. The color of the rock samples just or nearly after drilling will vary from that taken after few hours depending upon the weather condition on site as shown in (Figure 2).

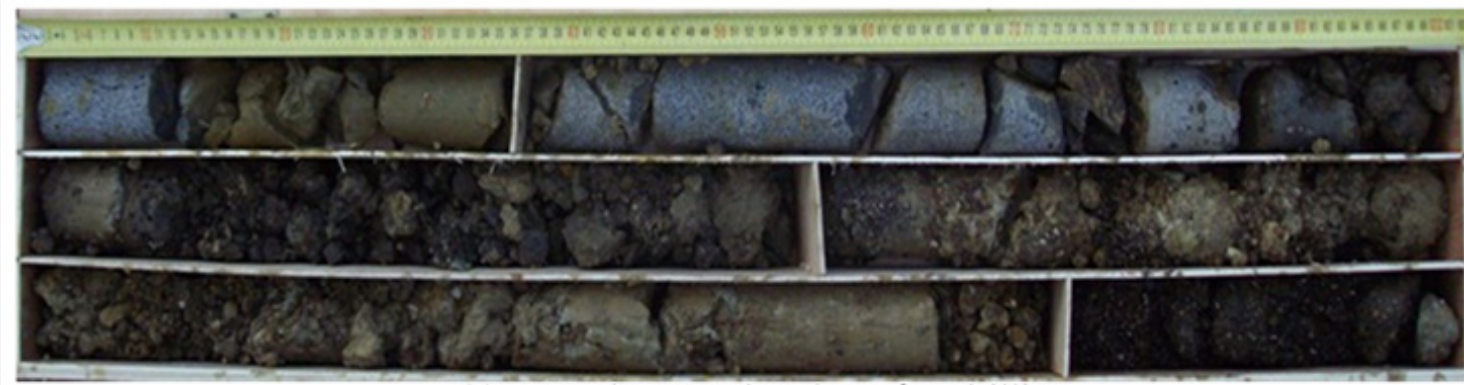

(a) Core photographs taken after drilling

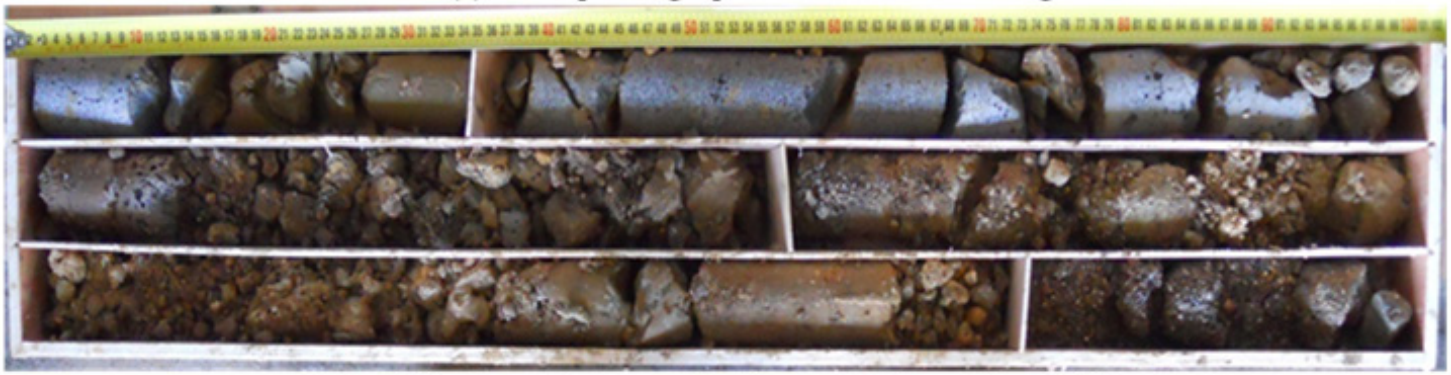

(b) Core photographs taken next day after drilling

Figure 2: Change of color in rock core samples with time.

The concept of soil rock mass ratio $[27,28]$ seems to be a better option to quantify the grade of weathering. Some of the researchers [33] have tried to gauge rate of weathering in relation with specific secondary mineral formation with the help of $14 \mathrm{C}$ methods. However, the soil mass ratio will again depends upon the friability or slaking nature of the rock mass and the environmental conditions to which it is further exposed to. Interestingly, most of the classification systems are based upon the changes in index properties of the weathered rock mass. A very few attempts [11] have been made to relate weathered rocks with its engineering properties. It can be mentioned here that some of the field test results like standard penetration test (SPT) blow count and the shear and compression wave velocities can precisely represent the weathering state in different rock mass. Donald et al. [19] suggested that the percentage of core recovery is an indication of soundness and degree of weathering 


\section{Civil Engineering Research Journal}

of rock. Hence it is very important that relative measurements of rock quality is made by comparing ratios of field values of compression or shear wave velocities to laboratory values. Otherwise, it better to rate the weathering directly from the field tests like SPT, CPT or Pressure meter tests. With a difference from the other classification systems, Price [4] pointed out that in the description of mass weathering for engineering purposes, the uniformity or regularity and style of weathering is a key issue. Keeping this in view, he suggested to classify mass weathering as uniform(ly) weathered; complex(ly) weathered; core stone weathered or solution weathered.

Due to the fact that a large range of rock types and masses and weathering processes exists, there are many possibilities for future classifications of particular rock masses weathered in particular environments. It is suggested that classification of weathering in rocks for engineering purposes should lie in simplification rather than elaboration, paying particular regard to establishing the boundary between that part of the weathered mass which will behave as an engineering soil and that which will behave as an engineering rock [4]. Although, the present grading systems are very useful, it still fails to quantify the changes in engineering properties of rocks, due to weathering.

\section{Engineering implications}

The purpose of grading weathered rocks is to provide an engineering classification of rock mass for a specific project [34-36]. Moreover, for that specific project, it is very important to analyze the state of weathering by considering the types of rock mass. An interesting example is that, weathered zones in rocks can be good aquifer, but it is not so, if filled with secondary clays produced during the weathering process [13]. Again, it is reported [29] that the trend line between permeability with degree of weathering is not very consistent in case of granite. Similarly, when the problem is related to slopes, the engineers would be more interested on the zones of weakness or discontinuities, occurred as a result of weathering or some other means [19]. However, if weathering of parent rocks results in an accumulation of weathering-resistant materials (such as, quartz, igneous and metamorphic siliceous grains, siliceous cement and chert), it will increase the abrasive character of the materials along the slopes [12].

In general, the strength and bearing capacity of rocks decrease as a result of weathering. Contradictorily, dissolution and subsequent precipitation of carbonates below the ground surface increase the grain contacts due to cementation and hence increase the strength of loose sedimentary deposits. In addition to this, weather ability of some of the rocks like shale's and mudstones is extremely variable, and rocks that are likely to degrade on exposure should be further characterized by use of tests for durability under standard drying and wetting cycle. If, for example, wetting and drying cycles reduce shale to grain size, and then rapid slaking and erosion in the field is probable when rock is exposed [37]. The above mentioned are a few of the examples, that highlights the responsibilities of the engineers and designers, when dealing with weathered rocks.

\section{Concluding Remarks}

Weathering in rocks is a subjective term and hence it is difficult to quantify it. However, problems in weathered rocks can be tackled easily with proper interpretation of the data available, both at the material and mass level. The descriptive terms commonly used for classification of weathered rocks are mostly the index properties of rocks and are subjective in nature. Attempts should be made to correlate the weathering state of rocks to its engineering properties.

\section{References}

1. Reiche P (1950) A survey of weathering processes and products. University of New Mexico Publications in Geology, 3, University of New Mexico Press, New Mexico, United States.

2. Ollier C (1991) Ancient Landforms. Belhaven Press, India.

3. Selby MJ (1993) Hill slope Materials and Processes. Oxford University Press, India.

4. Price DG (1995) Weathering and weathering processes. Quarterly Journal of Engineering Geology 28: 243-252.

5. Anon (1970) The logging of rock cores for engineering purposes. Quarterly Journal of Engineering Geology 3: 1-24.

6. Dearman WR (1976) Weathering classification in the characterization of rock: a revision. Bulletin of the International Association of Engineering Geology 13:123-127.

7. Dearman WR (1986) State of weathering: the search for a rational approach. In: AB Hawkins, (Ed.), site Investigation Practice: Assessing BS5930, Geological Society, Engineering Geology. ( $\left.2^{\text {nd }} e d n\right)$, Special Publication, London, UK, pp. 132-142.

8. Cragg DJ, Ingrnan J (1995) Rock weathering descriptions: current difficulties. Quarterly Journal of Engineering Geology 28: 277-286.

9. Bin SA, Hongtao J, Zhibin L, Fang HY (2002) Engineering geological characteristics of expansive soils in China. Engineering Geology 67: 63-71.

10. Christopher DP, Baxter, Matthew JP, Aaron SB, Michael S (2005) Guidelines for geotechnical site investigations in Rhode Island, RIDOT Study - 0103, Departments of Ocean/Civil and Environmental Engineering University of Rhode Island, Kingston, RI 02881, USA.

11. Gu DX, Tamblyn W, Lamb I, Ramsey N (2008) Effect of weathering on strength and modulus of basalt and siltstone. American Rock Mechanics Association, California, USA.

12. Lempe B, Scholz H, Thuro K (2010) The influence of weathering on the geotechnical properties of Pleistocene coarse grained glaciofluvial deposits in the northern Alpine foreland. In: Williams et al. (Eds.), Geologically Active. Taylor and Francis Group, London.

13. Hencher SR, McNicholl DP (2005) Engineering in weathered rock. Quarterly Journal of Engineering Geology 28: 253-266.

14. Clayton CRI, Matthews MC, Simons NE (1997) Site investigation.

15. Dobie MJD (1987) Slope instability in a profile of weathered no rite. Quarterly Journal of Engineering Geology 20: 279-286.

16. Hudec PP (1998) Rock properties and physical processes of rapid weathering and deterioration. $8^{\text {th }}$ International IAEG Congress, Balkema, Rotterdam, Netherlands. 


\section{Civil Engineering Research Journal}

17. ISRM International Society for Rock Mechanics (1978) Suggested method for petro graphic description of rocks 15 (2): 41-46.

18. Catto NR (1983) Loess in the Cypress Hills, Alberta, Canada. Canadian Journal of Earth Science 20(7):159-167.

19. Donald LB, Ferguson KI, Wright JW, Moy GW (2005) Soil Mechanics. Unified Facilities Criteria (UFC), UFC 3-220-10N, p. 394.

20. Ferrier KL, Kirchner JW, Riebe CS, Finkel RC (2010) Mineral-specific chemical weathering rates over millennial timescales: Measurements at Rio Icacos, Puerto Rico. Chemical Geology 277: 101-114.

21. Balasubramaniam MS, Alasubramaniam MS, Waheed U (1977) Deformation characteristics of weathered Bangkok clay in triaxial extension. Geotechnique 27(1): 75-92.

22. Martin RP, Hencher SR (1986) Principles for description and classification of weathered rocks for engineering purposes. In AB Hawkins (Ed.), Site Investigation Practice: Assessing BS5930, Geological Society, London, Engineering Geology Special Publication, 2: 299-308.

23. Shi B, Jiang H, Liu Z, Fang HY (2002) Engineering geological characteristics of expansive soils in China. Engineering Geology 67: 63-71.

24. Higgs NB (1976) Slaking basalts. Bulletin of the Association of Engineering Geologists 13: 151-161.

25. Haskins DR, Bell FG (1995) Drakensberg basalts: their alteration, breakdown and durability. Quarterly Journal of Engineering Geology 28: 287-302.

26. Moye DG (1955) Engineering geology of the Snowy Mountains scheme. Journal of Institute of Engineers of Australia 27: 281-299.

27. Roxton RB, Berry L (1957) Weathering of granite and associated erosional features in Hong Kong. Bulletin of the Geological Society of America 68(10): 1263-1292.

28. Little AL (1967) Laterites. Proceedings of the $3^{\text {rd }}$ Asian Conference on Soil Mechanics and Foundation Engineering, Haifa 2: 61-71.
29. Anon (1981) Code of practice for site investigations (BS5930). British Standards Institution, London.1990. Geological Society Engineering Group Working Party Report: Tropical Residual Soils. Quarterly Journal of Engineering Geology 23: 1-101.

30. Stapledon DH (1976) Geological hazards and water storage. Bulletin of the International. Association Engineering Geology 14: 249-262.

31. Dames, Moore (1983) Mass Rapid Transit System, Singapore: Detailed Geotechnical Study. Interpretative Report, Provisional Mass Rapid Transit Authority, Singapore.

32. Komoo I, Mogana SN (1988) Physical characterization of weathering profiles of classic met sediments in Peninsular Malaysia. In: Proceedings of the $2^{\text {nd }}$ Conference on Geomechanics in Tropical Soils, Singapore 1: 37-42.

33. Schroeder PA, West L T (2005) Weathering profiles developed on granitic, mafic and ultramafic terrains in the area of Elberton, Georgia. Georgia Geological Society Guidebook 25: 55-80.

34. Knill JL, Jones KS (1965) The recording and interpretation of geological conditions in the foundations of the Roseires, Kariba and Latiyan dams. Geotechnique 15: 94-124.

35. Ward WH, Burland JB, Gallois RW (1968) Geotechnical assessment of a site at Mundford, Norfolk, for a large proton accelerator. Geotechnique 18(4): 399-431.

36. Chandler RJ (1969) The effect of weathering on the shear strength properties of Keuper Marl. Geotechnique 19(3): 321-334.

37. Franklin JA, Broch E, Walton G (1971) Logging Mechanical Character of Rock, Institution of Mining and Metallurgy an 80: A1-A9.

38. Engineering Group of Geological Society Working Party (1995) Description and classification of weathered rock for engineering purposes. Quarterly Journal of Engineering Geology28 (2).

\section{Your next submission with Juniper Publishers will reach you the below assets}

- Quality Editorial service

- Swift Peer Review

- Reprints availability

- E-prints Service

- Manuscript Podcast for convenient understanding

- Global attainment for your research

- Manuscript accessibility in different formats

( Pdf, E-pub, Full Text, Audio)

- Unceasing customer service

Track the below URL for one-step submission https://juniperpublishers.com/online-submission.php 